\title{
A TÁRSADALMI FELELŐSSÉGVÁlLALÁS JELENLÉTE A MAGYAR ÁLLAMI EGYETEMEK SZERVEZETI DOKUMENTUMAIBAN
}

\author{
DÁNOS ZSOLT \\ Széchenyi István Egyetem, Regionális- és Gazdaságtudományi Doktori Iskola \\ Beérkezett: 2020, július 10., elfogadva: 2021, január 21.
}

\begin{abstract}
A tanulmány a magyarországi állami felsőoktatási intézmények honlapjain elérhető szervezeti dokumentumokban tartalomelemzés segítségével keresi az alig két évtizedes múltra visszatekintő egyetemi társadalmi felelősségvállalás jelenlétét. A fogalom, amely az egyetem modern szerepeinek értelmezését tágítja, a vállalati társadalmi felelősségvállalás nyomán tünt fel, összekapcsolódva a harmadik misszió jelenségével. Emellett az írás kategóriákat kíván felállítani arra vonatkozólag, hogy az egyetemi társadalmi felelősségvállalás hogyan jelenik meg és milyen tudatosságot képvisel az intézmények felelősségvállalásában. A tanulmány mindehhez bemutatja azokat a kereteket, amelyekben az egyetemi társadalmi felelősségvállalás fogalma kialakult.
\end{abstract}

Kulcsszavakः egyetemi társadalmi felelősségvállalás, magyar felsőoktatás, szervezeti dokumentumok, tartalomelemzés

The study uses the method of content analysis in the organizational documents available on the institutional websites of Hungarian higher education to look for the presence of university social responsibility, which dates back only two decades. The concept emerged in the wake of corporate social responsibility in connection with the phenomenon of the third mission and seeks to broaden the interpretation of the modern roles of the university, but it has hardly been researched in the Hungarian research. Besides, the writing seeks to establish categories of how university social responsibility manifests itself and what awareness the institution represents in responsibility. For all this, the study presents the framework in which the concept of university social responsibility has been developed.

Keywords: university social responsibility, Hungarian higher education, organizational documents, content analysis

Levelező szerző: Dános Zsolt, Széchenyi István Egyetem RGDI, 9026 Győr, Egyetem tér 1.

E-mail: danos.zsolt@gmail.com 


\title{
Bevezetés
}

\begin{abstract}
A tanulmány annak bemutatására törekszik, hogy az egyetemi társadalmi felelősségvállalás milyen módon és mértékben jelent meg a hazai felsőoktatásban, és ehhez az egyes állami egyetemek szervezeti dokumentumaiban való megjelenését és szerepét veszi alapul. Az írás célul tűzi ki, hogy minden állami egyetem ${ }^{1}$ szervezeti dokumentumai alapján igazolja az egyetemi társadalmi felelősségvállalás elterjedtségét, és kategóriákat kínáljon az egyetemi társadalmi felelősségvállalás intézményi rendszerezésére.
\end{abstract}

\section{Az egyetemi társadalmi felelősségvállalás}

Az egyetemi társadalmi felelősségvállalás történetének egyik mérföldkőjének tekinthető az 1988-as Magna Charta Universitatum, ami az európai egyetem értékeit foglalta magába, és igaz, erősen az akadémiai szféra szerepét emelte ki, de mégis hitet tett a társadalmi értékek formálásának feladata mellett. Jóval demokratikusabb szellemben fogant az 1998-as World Declaration címü UNESCO dekrétum, amely a felsőoktatás egészének társadalmi feladatait hangsúlyozta (Veroszta 2010). Az 1998-as dekrétum 2009-es megerösítése (The New Dynamics of Higher Education and Research For Societal Change and Development címü UNESCO-dekrétum) hasonlóan az előzményhez a felsőoktatás társadalmi felelősségét hangsúlyozza (Gurria 2009). Az 1998-as dekrétum nagyban hozzájárult a bolognai folyamat szellemi útkereséséhez is, az Európai Felsőoktatási Térség megszületésének egyik vezérmotívuma volt az oktatáshoz való hozzáférés lehetőségeinek javítása, illetve az ehhez kapcsolódó esélyegyenlőség támogatása (Hrubos 2008). Az Európai Unió mellett az UNESCO járul hozzá legerőteljesebben a felsőoktatási intézmények társadalmi felelősségvállalásához annak stratégiai irányelveinek megfogalmazásával. Az említett stratégiai dokumentumok nagyban hozzájárultak az egyetemi társadalmi felelősségvállalás értelmezési keretének, illetve szakirodalmi bázisának kialakulásához.

$\mathrm{Az}$ egyetemi társadalmi felelősségvállalás gondolatának első megjelenése Boyer (1996) nevéhez kötődik, aki az elkötelezettségi ösztöndíj (Scholarship of Engagement) koncepciójának megalkotója, ami az egyetemi társadalmi felelősségvállalás előfutárjának tekinthető. Korai értelmezéssel kísérletezett Bonnen (1998) is, és jelentős volt az egyetemi közösségi elkötelezettség (university civil engagement) kifejezés térhódítása is, amelyet az irodalomban az egyetemi társadalmi felelősségvállalás egyfajta előzetes szinonimájaként használtak (Esfijani-Hussain-Chang 2012). A 2000-es évek kutatási irányát elsősorban a fenntarthatóság egyetemi keretek között való értelmezése fedte le. Ezek a munkák többnyire az egyetemi működést próbálták meg olyan módon modellezni, hogy a fenntartható fejlödés szempontjai érvényesüljenek az egyetemi stratégiákban (Lukman-Glavic 2007; Velazquez et al. 2006). Itt kell megemlíteni az 1990-es Talloires-i nyilatkozatot, amely fontos kísérletet tett a fenntartható egyetem fogalmának meghatározására és a modellek alapját jelentette.

2020. június 1-jei állapot szerint. 
A fenntartható egyetem modellje mellett csak a 2000-es években jelent meg önálló fogalomként az egyetemi társadalmi felelősségvállalás, habár a fogalom által lefedett jelenség kutatása ezt jó néhány évvel megelőzte. A kezdeti modellek alapját a vállalati társadalmi felelősségvállalással való összehasonlítás és az attól való megkülönböztetés jellemezte (Jorge-Peña 2017). Jorge és Peña (2017) a 2000 és 2015 között publikált irodalom áttekintése után kísérelte meg összegezni az egyetemi társadalmi felelősségvállalás lényegét. Az egyetemi felelősségvállalásnak ma talán legelterjedtebb definíciója Vallaeys (2014) nevéhez füződik, akinél központi szerepet kap a helyi elkötelezettség és beágyazottság, valamint a demokratikus tudástermelés. Elképzelése szoros összefüggésben áll a zöld egyetem ideájával, és hitet tesz amellett, hogy a fenntarthatóság és a méltányos tanulás- és kutatásszervezés feltételezi, hogy a tudomány és a tudás nem értékesíthető termékek, mert közvetlenül az értékteremtésért felelnek. A kiemelt intézmények feladata ebben a felfogásban olyan morális felelősség, amely globális keretekben gondolkodik. Az egyetemeknek azonban ennek eléréséhez teljes rendszerüket át kell szervezniük (Vallaeys 2014).

A hazai egyetemek viszonylatában Bander (2011) végezte el azok küldetésnyilatkozatának elemzését, amelynek során tanulmányozta az összes hazai felsőoktatási intézmény honlapján (68 intézmény volt 2011-ben) elérhető vállalt intézményi küldetések tartalmát. 64 intézmény honlapján talált küldetésre utaló tartalmakat, amelyek közül harmadik misszió 58 intézménynél volt megfigyelhető valamilyen formában. A kutatás alapján a harmadik kategóriát alkotó társadalmi szerepvállalás és azon belül a szűkebb és tágabb környezetnek nyújtott szolgáltatások bizonyultak a felsőoktatási intézmények harmadik missziós legelterjedtebb dimenziójának. A szűkebb és tágabb társadalmi környezetnek nyújtott szolgáltatások így összesen 58 intézményben voltak megfigyelhetők.

Az egyetemi társadalmi felelősségvállalás nem köthető kizárólag a harmadik misszióhoz, érdemi része ide tartozik, de nem azonos vele. Az egyetem alaptevékenységei megfeleltethetők felelős társadalmi tevékenységnek, nincs ellentmondás az alaptevékenység és a felelős társadalmi magatartás között, ami azzal jár, hogy mind az oktatásnak, mind a kutatásnak van olyan dimenziója, ami az egyetemi társadalmi felelősségvállalásban is értelmezhető. Ebből látható, hogy az egyetemi társadalmi felelősségvállalás inkább horizontális fogalom, mint az egyes missziókhoz köthető alkategória, ugyanakkor kétségtelen, hogy leginkább a harmadik misszióhoz áll közel, és a kapcsolódó tevékenységek jó része ehhez a misszióhoz kötődik.

\section{A kutatás célja és módszertana}

Az elemzés egy olyan kutatáshoz kapcsolódott, amelynek elsődleges célja annak megállapítása volt, hogy az egyetemi társadalmi felelősségvállalás milyen formában és hogyan jelenik meg a hazai intézmények körében. A kutatáshoz szükséges volt az egyetemi társadalmi felelősségvállalás és az ahhoz kapcsolódó fogalmak jelenlétének és ismeretének felmérése is, illetve annak vizsgálata, hogy ezek mennyire épülnek be az intézmények stratégiai rendszerébe és mennyire fedezhetők fel azok gondolkodásában. 
A vizsgálat során összesen huszonegy egyetem ${ }^{2}$ szervezeti dokumentációjának elemzésére került sor, mely egyetemek kiválasztását az alábbi szempontok indokolták:

- a nemzeti felsőoktatásról szóló 2011. évi CCIV. törvény 1. melléklete tartalmazza ezeket az intézményeket, mint Magyarország államilag elismert felsőoktatási intézményeit;

- mindegyik a vizsgálat lezárásáig, 2020. május 31-ig az állami (fenntartású) egyetemek csoportjába tartozik, azaz a fenntartásukat állami szervezet látja el, illetve egyetemi besorolásúak, ami jogi szempontból elválik az ún. alkalmazott tudományok egyetemi csoportjától.

A z így kiválasztott egyetemek a hazai szabályozásban homogén besorolást alkotnak, ami alkalmassá teszi önálló klaszterként való vizsgálatukat, ugyanakkor összetételüket tekintve is kellően változatosak, azaz a kutatás céljának megfelelően csoportosíthatók. A kezdeti csoportosítás során figyelembe vettük Bander (2011) kutatásának csoportképző elemeit is:

- Klasszikus egyetemek: Debreceni Egyetem (DE), Eötvös Loránd Tudományegyetem (ELTE), Pécsi Tudományegyetem (PTE), Szegedi Tudományegyetem (SZTE);

- Széles profilú, de a klasszikustól eltérő szakmai összetételü egyetemek: Budapesti Müszaki és Gazdaságtudományi Egyetem (BME), Kaposvári Egyetem (KE), Miskolci Egyetem (ME), Óbudai Egyetem (ÓE), Pannon Egyetem (PE), Soproni Egyetem (SoE), Szent István Egyetem (SZIE), Széchenyi István Egyetem (SZE);

- Speciális profilú, viszonylag kis egyetemek: Állatorvostudományi Egyetem (ÁTE), Liszt Ferenc Zeneművészeti Egyetem (LFZE), Magyar Képzőművészeti Egyetem (MKE), Magyar Táncművészeti Egyetem (MTE), Moholy-Nagy Művészeti Egyetem (MOME), Színház- és Filmművészeti Egyetem (SFE), Testnevelési Egyetem (TE);

- Speciális profilú, viszonylag nagy egyetemekः Nemzeti Közszolgálati Egyetem (NKE), Semmelweis Egyetem (SE).

A vizsgálat hipotézise szerint ez az egyetemi kategorizálás a társadalmi felelősségvállalás szempontjából is releváns csoportosítást jelent. Ennek alátámasztásához az alábbi egyetemi dokumentumok elemzésére került sor:

- intézményfejlesztési terv(ek),

- vízió (vagy ezzel egyenértékű szervezeti dokumentum),

- misszió vagy küldetésnyilatkozat,

- minőségpolitikai vagy minőségirányítási dokumentumok,

- szervezeti és múködési szabályzat,

- esélyegyenlőségi terv (vagy ezzel egyenértékű szervezeti dokumentum),

- fenntarthatósági stratégia (vagy ezzel egyenértékű szervezeti dokumentum).

2 Az egyetemek: Állatorvostudományi Egyetem (ÁTE), Budapesti Műszaki és Gazdaságtudományi Egyetem (BME), Debreceni Egyetem (DE), Eötvös Loránd Tudományegyetem (ELTE), Kaposvári Egyetem (KE), Liszt Ferenc Zeneművészeti Egyetem (LFZE), Magyar Képzőművészeti Egyetem (MKE), Magyar Táncművészeti Egyetem (MTE), Miskolci Egyetem (ME), Moholy-Nagy Müvészeti Egyetem (MOME), Nemzeti Közszolgálati Egyetem (NKE), Óbudai Egyetem (ÓE), Pannon Egyetem (PE), Pécsi Tudományegyetem (PTE), Semmelweis Egyetem (SE), Soproni Egyetem (SoE), Szegedi Tudományegyetem (SZTE), Szent István Egyetem (SZIE), Széchenyi István Egyetem (SZE), Színház- és Filmmúvészeti Egyetem (SZFE), Testnevelési Egyetem (TE). 
A dokumentumokat kvantitatív tartalomelemzési módszerrel elemeztünk, amelynek keretében az érintett egyetemek felsorolt dokumentumaiban meghatározott kulcsszavak előfordulásának gyakoriságát vizsgáltuk. A kulcsszavas keresés egyszerű dokumentumkereső funkcióval valósult meg. A kulcsszavak felmérését követően az egyes dokumentumokban elért kulcsszavas találatokat dokumentumonként és intézményenként összesítettük, majd összehasonlítottuk az elért eredményeket.

Az egyes szövegekben az alábbi kulcsszavakra, kifejezésekre kerestünk rá:

- társadalmi felelősségvállalás,

- harmadik misszió,

- jótékonyság,

- fenntarthatóság,

- fenntartható fejlődés,

- környezetvédelem,

- esélyegyenlőség,

- önkéntes,

- civil,

- rászoruló.

Az összevetés során vizsgáltuk, hogy a négy, előzetesen kialakított kategórián belül, amelynek kialakítása során az intézményi méreteket és a képzési profilt vettük alapul, az egyes intézményeknél elért eredmények milyen mértékben mutatnak hasonló képet. Amennyiben a vizsgálat az egyes kategóriákon belül hasonló eredményeket mutat, akkor az igazolja az előzetesen felállított intézményi kategóriák megfelelőségét. Az eltérő eredmények azonban új kategóriák felállítását teszik szükségessé.

\section{A szervezeti dokumentumok vizsgálatának eredményei}

A kiválasztott dokumentumkörök alátámasztottságát a kutatás igazolta. A dokumentumok jelentős része elérhető volt és rendelkezésre is állt (de nem minden intézménynél). Egyedül a vízió vizsgálata tekinthető sikertelennek, mivel víziót vagy jövőképet mindössze két intézménynél (Semmelweis Egyetem, Széchenyi István Egyetem) lehetett csak találni: az intézmények többsége vagy nem tüntette fel a víziót a honlapján, vagy nem önálló dokumentumként, más tartalmon belül voltak megtalálhatóak, illetve egyáltalán nem volt fellelhető ilyen dokumentum.

A kutatás során törekedtünk arra, hogy a hiányzó dokumentumok esetében is keressünk kapcsolódó tartalmakat, ezeket viszont csak abban az esetben vizsgáltuk, ha funkciójában a keresett dokumentumnak megfelelő volt. Amennyiben ilyen nem állt rendelkezésre, olyan tartalmakat kerestünk, amelyek hasonló szerepet tölthetnek be az intézmény külső és belső kommunikációjában, illetve utalásokat vagy kapcsolódó részeket kerestünk a hiányzó tartalomra, bár ezeket ezt követően csak indokolt esetben elemeztük. Minden intézménynél volt legalább egy vagy két elérhető és elemezhető dokumentum, de inkább három-öt anyag volt a jellemző.

A kifejezések meglétének vagy hiányának jelentősége kulcsszótól függően eltérő, de mindenképpen lényeges, hogy olyan kifejezésekről van szó, amelyeknek akár egyszeri jelenléte is igazolhatja tevékenységek vagy az egyetemi társadalmi felelősségvállaláshoz kapcsolódó gondolkodás jelenlétét és a tevékenységek művelését. A gyakoriság mind- 
ehhez mérten pedig a témához való tudatos és adott esetben fogalmilag is felvértezett viszonyulás jelzője lehet. Kétségtelenül fontos megemlíteni, hogy attól, hogy az intézmény stratégiai dokumentumaiban szerepel egy-egy keresőszó, még korántsem biztos, hogy abból aktív tevékenységek is fakadnak. Ezek mellett azért fontos a kulcsszavak megtalálhatósága, mert azok teljes hiánya viszont igen nagy valószínűség szerint valódi hiányt jelez, nem feltétlenül a kapcsolódó tevékenységek teljes hiányát, hanem sokkal inkább a témáról való szervezeti szintű gondolkodás, tudatos tervezés és végrehajtás, illetve a kommunikáció, transzparencia hiányát, amit pedig alapvetésnek kell tekintenünk az egyetemi társadalmi felelősségvállalás jelensége kapcsán.

A kutatás megerősítette Bander (2011) korábbi eredményeit, vagyis az egyetemi társadalmi felelősségvállalás mind az egyetemi stratégiai dokumentumokban, mind a mindennapi működésében jelen van a vizsgált intézményi körben. Minden intézménynél kimutatható volt a jelenlét, igaz, eltérő mértékben és intenzitással. Azt azonban mindenképpen le kell szögezni, hogy a még elkötelezettnek tekinthető intézmények esetében is hiányos a tevékenységek disszeminációja, és kevéssé áttekinthető a kommunikáció és az intézményesültség. Ez összekapcsolódik egy, az Egyesült Államokban végzett kutatás eredményeivel, ahol a nyilvánosság és az online információk biztosítása jóformán minden egyetemi típusban hiányos és elégtelen volt (Sánchez-Bolivar-López-Hernández 2013).

A szervezeti dokumentumok (intézményfejlesztési terv, vízió, küldetésnyilatkozat vagy misszió, minőségpolitikai vagy minőségirányítása dokumentum, szervezeti és müködési szabályzat) összesített kulcsszavas találatait az 1. táblázat mutatja be.

1. táblázat: Kulcsszavas találatok az egyes intézmények szervezeti dokumentumaiban

\begin{tabular}{|c|c|c|c|c|c|c|c|c|c|c|c|}
\hline 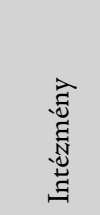 & 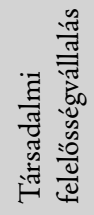 & 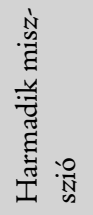 & 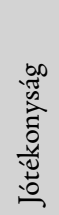 & 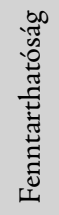 & 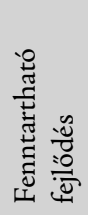 & 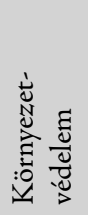 & 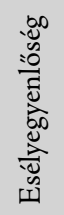 & :0 & $\bar{z}$ & 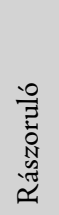 & 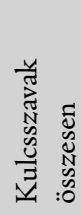 \\
\hline $\mathrm{DE}$ & 1 & 16 & 0 & 8 & 0 & 1 & 7 & 0 & 4 & 1 & 38 \\
\hline ELTE & 0 & 7 & 0 & 4 & 14 & 3 & 9 & 0 & 2 & 0 & 39 \\
\hline PTE & 3 & 4 & 0 & 4 & 0 & 0 & 6 & 9 & 5 & 0 & 31 \\
\hline SZTE & 9 & 26 & 0 & 5 & 4 & 2 & 8 & 0 & 4 & 0 & 58 \\
\hline BME & 0 & 6 & 0 & 4 & 1 & 10 & 3 & 1 & 1 & 0 & 26 \\
\hline $\mathrm{KE}$ & 4 & 7 & 0 & 2 & 1 & 3 & 5 & 0 & 2 & 2 & 26 \\
\hline ME & 0 & 0 & 0 & 1 & 1 & 16 & 31 & 1 & 3 & 0 & 53 \\
\hline ÓE & 5 & 5 & 0 & 1 & 0 & 4 & 11 & 1 & 6 & 1 & 34 \\
\hline PE & 2 & 11 & 0 & 5 & 0 & 1 & 1 & 0 & 0 & 0 & 20 \\
\hline SoE & 0 & 2 & 0 & 22 & 17 & 8 & 8 & 0 & 5 & 1 & 63 \\
\hline SZIE & 0 & 5 & 0 & 2 & 5 & 12 & 2 & 0 & 1 & 0 & 27 \\
\hline SZE & 2 & 7 & 0 & 3 & 2 & 0 & 1 & 0 & 1 & 0 & 16 \\
\hline ÁTE & 0 & 0 & 0 & 0 & 0 & 3 & 0 & 0 & 0 & 0 & 3 \\
\hline LFZE & 0 & 11 & 0 & 2 & 1 & 1 & 10 & 0 & 3 & 1 & 29 \\
\hline
\end{tabular}


1. táblázat: (folyt.)

\begin{tabular}{|c|c|c|c|c|c|c|c|c|c|c|c|}
\hline 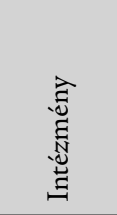 & 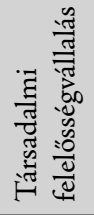 & 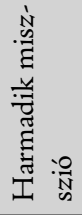 & 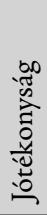 & 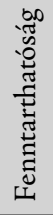 & 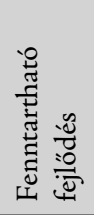 & 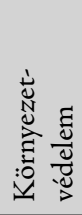 & 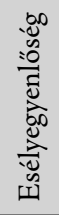 & :0 & $\begin{array}{l}\overline{3} \\
\bar{U}\end{array}$ & 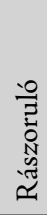 & 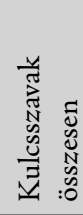 \\
\hline MKE & 0 & 0 & 0 & 0 & 0 & 1 & 0 & 0 & 0 & 0 & 1 \\
\hline MTE & 0 & 6 & 0 & 0 & 0 & 1 & 0 & 0 & 0 & 0 & 7 \\
\hline MOME & 0 & 0 & 0 & 39 & 7 & 4 & 9 & 2 & 3 & 0 & 64 \\
\hline SZFE & 0 & 0 & 0 & 0 & 0 & 0 & 5 & 3 & 1 & 0 & 9 \\
\hline TE & 0 & 0 & 0 & 0 & 0 & 0 & 8 & 2 & 0 & 0 & 10 \\
\hline NKE & 2 & 1 & 0 & 14 & 15 & 5 & 1 & 3 & 12 & 0 & 53 \\
\hline SE & 2 & 4 & 0 & 5 & 0 & 3 & 12 & 1 & 0 & 0 & 27 \\
\hline
\end{tabular}

Forrás: Saját szerkesztés

A 2. táblázatban kategóriánként összegzett eredményekből látható, hogy az egyes kategóriákon belül jelentős eltérések tapasztalhatók, ami felveti a kérdést, hogy az egyes egyetemek valóban az előzetesen létrehozott csoportokba sorolhatók.

2. táblázat: $\mathrm{Az}$ egyes csoportok összesített eredményei a szervezeti dokumentumokban végzett kulcsszavas keresés kapcsán

\begin{tabular}{|c|c|c|c|c|c|c|}
\hline $\begin{array}{l}\text { Intézményi kategóriák méret és } \\
\text { profil szerint }\end{array}$ & 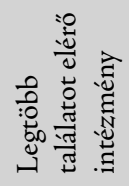 & 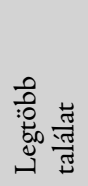 & 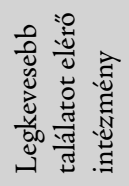 & 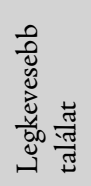 & 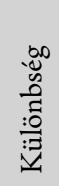 & 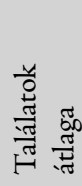 \\
\hline Klasszikus egyetemek & SZTE & 58 & PTE & 31 & 27 & 41,5 \\
\hline $\begin{array}{l}\text { Széles profilú, de a klasszikustól } \\
\text { eltérő szakmai összetételű } \\
\text { egyetemek }\end{array}$ & SoE & 63 & SZE & 16 & 47 & 33,1 \\
\hline $\begin{array}{l}\text { Speciális profilú, viszonylag kis } \\
\text { egyetemek }\end{array}$ & MOME & 64 & MKE & 1 & 63 & 17,6 \\
\hline $\begin{array}{l}\text { Speciális profilú, viszonylag } \\
\text { nagy egyetemek }\end{array}$ & NKE & 53 & SE & 27 & 26 & 40,0 \\
\hline Összes kategória & MOME & 64 & MKE & 1 & 63 & 30,2 \\
\hline
\end{tabular}

Forrás: Saját szerkesztés

$\mathrm{A} z$ egyes kategóriákon belül látható jelentős eltérések felvetik a kérdést, hogy az egyes egyetemek valóban az elözetesen létrehozott csoportokba sorolhatók-e? A kérdés megválaszolását segíti a láthatóság, a transzparencia vizsgálata, hiszen az egyetemi társadalmi felelősségvállalásnak, mint minden felelősségvállalásnak, központi motí- 
vuma a tudatosság és a láthatóság. Az az egyetem, amelyik nem vagy nem tudatosan válogatja az ezekhez kapcsolódó tartalmakat, nincs tisztában ennek a jelenségnek a jelentőségével. Másrészt minél kisebb mennyiségű releváns tartalom elérhető, annál kevésbé feltételezhető, hogy az egyetem tudatosan irányítja a kapcsolódó tevékenységeit. A kulcsszavas kutatás eredményeként két csoportosítási dimenziót sikerült azonosítani: a látható tudatosság (a szervezeti dokumentumokban lévő kulcsszavak száma alapján) és a látható aktivitás (az egyetemi dokumentumokban található tevékenységek mértéke) szintje. Ezek alapján a 21 vizsgált felsőoktatási intézmény esetében a 3. táblázatban bemutatott csoportosítás és besorolás körvonalazható.

3. táblázat: A kulcsszavas kutatást követő intézményi kategóriák az egyetemi társadalmi felelősségvállalás kapcsán

\begin{tabular}{lccc}
\hline $\begin{array}{l}\text { Látható aktivitás / látható } \\
\text { tudatosság }\end{array}$ & $\begin{array}{c}\text { Átlag feletti látható } \\
\text { tudatosságú } \\
\text { egyetemek }\end{array}$ & $\begin{array}{c}\text { Átlagos látható } \\
\text { tudatosságú } \\
\text { egyetemek }\end{array}$ & $\begin{array}{c}\text { Átlag alatti látható } \\
\text { tudatosságú } \\
\text { egyetemek }\end{array}$ \\
\hline $\begin{array}{l}\text { Kiemelkedő látható aktivitású } \\
\text { egyetemek }\end{array}$ & SZTE & SE & - \\
\hline $\begin{array}{l}\text { Magas látható aktivitású } \\
\text { egyetemek }\end{array}$ & - & ELTE & SZE \\
\hline $\begin{array}{l}\text { Közepes látható aktivitású } \\
\text { egyetemek }\end{array}$ & SoE & BME & TE \\
& NKE & OE & \\
\hline $\begin{array}{l}\text { Alacsony látható aktivitású } \\
\text { egyetemek }\end{array}$ & ME & SZIE & PE \\
& MOME & PE & ÁTE \\
& & KE & MKE \\
& & LFZE & MTE \\
& & & SZFE \\
\hline
\end{tabular}

Forrás: Saját szerkesztés

A látható aktivitás tekintetében négy dimenziót sikerült megkülönböztetni, míg a látható tudatosság esetében hármat. Az így létrejött 12 kategóriában valamennyi egyetem elhelyezhető és csak két halmaz maradt üresen, emellett ez a kategorizálás alkalmas lehet bármelyik másik egyetem besorolására.

\section{Összefoglalás}

A tanulmány célul tűzte ki, hogy a magyar felsőoktatási intézmények minél szélesebb platformján megvizsgálja az egyetemi társadalmi felelősségvállalás jelenlétét, elsősorban a szervezeti dokumentumok szintjén, így járulva hozzá a fogalom pontosabb hazai megértéséhez is. Az egyetemi társadalmi felelősségvállalás több szempontból nehezen megkerülhető része a mai felsőoktatás kutatásának, elsősorban azért, mert szorosan kötődik az egyetemek harmadik missziójához, ami kulcsfontosságú szerepet játszik abban, hogy a modern egyetem szerepe látható és érthető legyen a külső szereplők számára is. Ezenkívül fontos megjegyezni, hogy a társadalmi felelősségvállalás modern fogalmának értelmezése és elemzése segítséget nyújt abban is, hogy az egyetem történeti szerepe 
és társadalmi elvárásokhoz való illeszkedése szélesebb horizonton és történelmi távlatokban is átláthatóbb legyen. Az egyetemi társadalmi felelősségvállalás formájának és jellegének kutatása éppen ezért jelent fogódzót ahhoz, hogy megértsük, a ma egyeteme miben különbözik a néhány évtizeddel korábbitól.

Az elemzés rámutatott arra, hogy az egyetemi társadalmi felelősségvállalás valamilyen formája és mértéke minden vizsgált hazai intézményben megtalálható. Fontos tapasztalat, hogy nem volt olyan dokumentumtípus, amely minden intézménynél vizsgálható lett volna. Ezért óvatossággal kell kezelni az eredményeket, de ez az eredmény rámutat a láthatóság, transzparencia kérdéskörére, ami egészen egyedi értelmezési lehetőséget biztosít a kutatás eredményeinek. A szervezeti dokumentumok vizsgálatának folyamatát alapvetően meghatározta és behatárolta az a kérdés, hogy mennyire tekinthető relevánsnak, az intézmény életében meghatározónak vagy akármilyen mértékben is szerepet játszónak egy-egy jelenség, ha arra közvetlenül vagy közvetve utaló kifejezések megjelennek (illetve nem jelennek meg) az intézmény meghatározó stratégiai dokumentumaiban.

Az elemzést követően sikerült egy olyan kategorizálást felállítani, ami egyaránt figyelembe tudja venni a tevékenységi szint aktivitását, illetve a tervezési szint tudatosságát. $\mathrm{A} z$ elemzés eredményei tehát egy lehetséges interpretációt mutatnak meg az egyetemi társadalmi felelősségvállalás értelmezésére és intézményi jelenlétének elemzésére, rendszerezésére. Az elkészült kategorizálás lehetőséget nyújt a további kutatásokra, más intézménytípusok vizsgálatára is, illetve hosszabb távon széles körü összehasonlító elemzések alapjául szolgálhat a hazai és a nemzetközi környezetben is.

\section{IRODALOM}

Bander K. (2011) Vállalt küldetések az intézményi honlapok alapján. In: Hrubos I. (ed.) Mühelytanulmányok. NFKK Füzetek 8. Budapesti Corvinus Egyetem Nemzetközi Felsőoktatási Kutatások Központja, Budapest. pp. 58-88.

Bonnen, J. T. (1998) The Land Grant Idea and the Evolving Outreach University. In: R. M. Lerner \& L. A. Simon (eds) University-Community Collaborations for the 21st Century: Outreach to Scholarship for Youth and Families. New York, Garland Press. pp. 25-70.

Boyer, E. L. (1996) The Scholarship of Engagement. Bulletin of the American Academy of Arts and Sciences, Vol. 49. No. 7. pp. 18-33.

Esfijani, A., Hussain, F. K. \& Chang, E. (2012) An Approach to University Social Responsibility Ontology Development through Text Analyses. Paper presented at the IEEE 5th International Conference on Human System Interactions, IEEE-HSI-2012.

Gurria, A. (2009) The New Dynamics of Higher Education and Research for Societal Change and Development. Introductory Remarks. UNESCO World Conference on Higher Education, 0507 2009. https://www.oecd.org/education/thenewdynamicsofhighereducation andresearchforsocietalchangeanddevelopment.htm [Letöltve: 2019. 09. 30.]

Hrubos I. (2008) A minőségkultúra ügye az Európai Felsőoktatási Térségben. Educatio, Vol. 17. No. 1. pp. 22-35.

Jorge, M. L. \& Peña, F. J. A. (2017) Analysing the Literature on University Social Responsibility: A Review of Selected Higher Education Journals. Higher Education Quarterly, Vol. 71. No. 4. pp. 302-319. 
Lukman, R. \& Glavic, P. (2007) What Are the Key Elements of a Sustainable University? Clean Technologies and Environmental Policy, Vol. 9. No. 2. pp. 103-114.

Sánchez, R. G., Bolívar, M. P. R. \& López-Hernández, A. M. (2013) Online Disclosure of University Social Responsibility: A Comparative Study of Public and Private US Universities. Environmental Education Research, Vol. 19. No. 6. pp. 709-746.

Vallaeys, F. (2014) University Social Responsibility: A Mature and Responsible Definition. In: Higher Education in the World 3. Palgrave Macmillan. pp. 88-96.

Velazquez, L., Munugia, N., Platt, A. \& Taddei, J. (2006) Sustainable University: What Can Be the Matter? Journal of Cleaner Production, Vol. 14. Nos 9-11. pp. 810819.

Veroszta Zs. (2010) Felsőoktatási értékek - ballgatói szemmel. A felsőoktatás küldetésére vonatkozó hallgatói értékstruktúrák feltárása. Doktori értekezés. Budapesti Corvinus Egyetem, Társadalomtudományi Kar, Szociológia Doktori Iskola, Budapest.

World Declaration on Higher Education for the Twenty-first Century: Vision and Action (1998) World Conference on Higher Education. UNESCO, Paris. https://unesdoc. unesco.org/ark:/48223/pf0000113779?posInSet=3\&queryId=77779065-8b384a19-b92b-995515487455 [Letöltve: 2020.05. 30.]

A cikk a Creative Commons Attribution 4.0 International License (https://creativecommons.org/licenses/ by/4.0/) feltételei szerint publikált Open Access közlemény, melynek szellemében a cikk bármilyen médiumban szabadon felhasználható, megosztható és újraközölhető, feltéve, hogy az eredeti szerző és a közlés helye, illetve a CC License linkje és az esetlegesen végrehajtott módosítások feltüntetésre kerülnek. (SID_1) 